\title{
Economics Analysis of Guava Production in Haryana
}

\author{
Veer Sain, V. P. Luhach, Mohinder Singh Mehla and *ved jyoti \\ Research Schloar, Senior Scientist and *research scholar (ICG IIS Univ.) \\ Deptt. of Agriculture Economics, CCS, Haryana Agricultural University, Hisar-125004 (Haryana)
}

\begin{abstract}
The present study was conducted in Hisar district, Hansi, Barwala Block, and Fatehabad district Bhuna, Fatehabad Block and Sirsa district Baraguda, Sirsa Block of Haryana which was selected purposively on basis of highest area and production under Guava cultivation. Further, Hisar, Fatehabad and Sirsa market were selected for the market study. Finally 60 growers from randomly selected two blocks from each district were selected for the present study. On the basis of the nature of the data, budgeting technique and various economic tools were used for estimation of marketing margins, marketing price spread and marketing efficiency. The establishment cost was slight higher in Fatehabad as compared to Sirsa and then Hisar which was due to better management of orchard the largest item of expenditure was cost of irrigation which was worked out in Hisar, Fatehabad, Sirsa as overall average cost of irrigation. The overall average operational cost of guava orchard increased from first year to seventh year. The overall average operational cost per hectare per annum from first to seventh years were found to be on plant protection, manures and fertilizers. The overall average net returns from the intercropping range from Rs. 39371 in the first year to Rs. 25438 per hectare during the fifth year of the orchard.
\end{abstract}

\section{Introduction}

Guava fruit is commercially grown throughout the country. In India, production of guava is 2.27 Metric Tons with an area coverage of 0.20 million hectares (Kumar et al., 2010). In Haryana, production of guava is 0.053 Metric Tons with an area coverage of 0.007 million hectares (Anonymous, 2010). In the process of production of guava, marketing plays a vital role and it is a part and parcel of production.

In the process of marketing the producer has to incur various marketing costs. These costs are determined by the producer's performance and efficiency of different marketing functionaries which in turn influence the returns to the growers. Guava is a sub-tropical fruit. It is one of the most common and major fruit of India and considered the fifth most important fruit in area and production after mango, banana, citrus and apple with annual production. Hence the guava is called as "Garibanche safarchand". (Naphade and Tingre 2008). Hence study on the cost and returns aspects may provide some guidelines about the estimation of cost and returns of guava. In this context, the study was undertaken with the following specific objectives:

1. To study the estimation of establishment cost of guava in different district of Haryana

2. To work out the operational cost from guava orchard in different district of Haryana

3. To estimate the cost and returns from guava orchard in different district of Haryana

\section{Methodology}

The present study was conducted in Hisar district, Hansi, Barwala Block and Fatehabad district Bhuna, Fatehabad Block and Sirsa district Baraguda, Sirsa Block of Haryana, which was selected purposively on basis of highest area and production under Guava cultivation. Further, Hisar, Fatehabad and Sirsa market were selected for the market study during 2011-2012. Finally 60 growers from randomly selected two blocks from each district were selected for the present study. On the basis of the nature of the data, budgeting technique and various economic tools were used for estimation of cost and retuns of production of guava.

Table 1: District wise area under Guava fruit crop during year 2011-12

\begin{tabular}{|l|l|l|l|}
\hline Sr. No. & Districts & Total area & Production \\
\hline 1. & Hisar & 921 & 2820 \\
\hline 2. & Fatehabad & 356 & 3250 \\
\hline 3. & Sirsa & 191 & 2031 \\
\hline
\end{tabular}

Area in Hectare; Production in Tonnes

Analytical tools

Selection of blocks

From the above selected districts, In Hisar (Hansi and Barwala), Fatehabad (Bhuna and Fatehabad) and Sirsa (Sirsa and Baragudha) blocks having the largest area under the guava cultivation were selected for the present study. 
Selection of markets For estimating marketing cost, margin and price spread of guava, a sample of six whole- salers / commission agents which were companies - Rama fruit company, Bihari lal firm in Hisar and Saini fruit company, Goldi fruit company and Sayam fruit company, Goldi fruit company in Fatehabad and Sirsa district, selected randomly. Six pre-harvest contractors' and twelve retailers from fruit markets were selected randomly.

\section{Selection of villages}

A list of all the guava growing villages of Hansi and Barwala block in Hisar district, Bhuna and Fatehabad block in Fatehabad district and Baragudha and Sirsa in Sirsa district were obtained from District Horticulture Development Office. Four villages in Hisar, Fatehabad and Sirsa district were selected from two blocks. Ten farmers were selected from each block i.e. five farmers from each village where surveyed constituting the sample size of sixty farmers.

\section{Collection of Data}

Both primary as well as secondary data were used for attaining the objectives of the study undertaken.

Primary data on market basis were collected on marketing cost, purchase price sale prices etc. from the selected intermediaries involved in the selected marketing channels.

\section{Economics of guava production}

To analyze the economics of production, it is essential to study the cost in two parts viz., establishment costs and operational costs. The former consists of preparation of land and layout, digging and filling of pits, cost of plant and plant materials, cost of plant protection, cost of manures and fertilizes (incurred before plantation), cost of supporting structure and fencing. While recurring and maintenance costs include the expenditure on manuring (farm yard manure and fertilizer), interculture, irrigation, plant protection, pruning and cutting, opportunity cost (rental value of land), depreciation, on fixed investment and interest on fixed and working capital. For analysis of cost data, budgeting technique was used.

\section{Depreciation and interest}

For estimating annual cost, the depreciation has been worked out @ 4 per cent per annum at the fixed investment (i.e. establishment cost) by applying straight line method or direct method, assuming the life of orchard about 25 years. Further, interest has been taken@12 per cent per annum on operational cost.

\section{Amortization of fixed cost}

The annual amortization of cost was computed from the investment made on establishment of guava orchard, assuming that the rate of interest 12 per cent per annum and the expected life of guava orchard to be 25 years. Thus, annual amortization was worked out by using the compounding cost formula and by adding it to maintenance cost for estimating the annual cost of cultivation of guava orchard of respective farmers.

Where,

$$
I=B \frac{i}{1-(1+i)^{n}}
$$

$\mathrm{I}=$ Annual cost (in Rs)

$\mathrm{B}=$ Present fixed cost (in Rs),

$\mathrm{i}=$ Interest rate $(12 \%$ per annum $)$, and

$\mathrm{n}=$ Economic life of the orchard (in years).

\section{Results And Discussion:}

The establishment cost was slight higher in Fatehabad as compared to Sirsa and then Hisar which was due to better management of orchard (Table-1). The largest item of expenditure was cost of irrigation which was worked out in Hisar Rs.11500 (30.23 \%), Fatehabad Rs. 11000 (26.66 \%), Sirsa Rs. 11800 (28.71 \%) per hectare, constituting about and Rs. $11433(28.46 \%)$ as overall average cost of irrigation. Although cost of permanent fencing $(6.51 \%)$, cost of preparation of land, layout $(9.54 \%)$, digging and filling material $(2.77 \%)$ were also considered the other major component of the overall average establishment cost. Table- 2 showed that the overall average operational cost of guava orchard increased from Rs. 6152 in first year to Rs. 48709 per hectare in seventh year. The overall average operational cost per hectare per annum from first to seventh years were found to be Rs. 4748 on plant protection $(19.08 \%)$, Rs. 5431 on manures and fertilizers $(21.83 \%)$, Rs. 2828 on picking $(11.36 \%)$, Rs. 2371 on pruning and cutting $(9.52 \%)$, Rs. 2248 on intercultural operations and hoeing $(9.03 \%)$ followed by Rs. 1697 on irrigation and drip maintenance $(6.81 \%)$. Similar findings were also reported by Umesh et al. (2005). 
Table 1: Establishment cost of guava orchard

\begin{tabular}{|c|c|c|c|c|c|}
\hline Sr. No. & Particulars & Hisar & Fatehabad & Sirsa & overall average \\
\hline 1 & Peparation of land and layout & $\begin{array}{l}3650 \\
(9.59)\end{array}$ & $\begin{array}{l}4000 \\
(9.69)\end{array}$ & $\begin{array}{l}3850 \\
(9.36)\end{array}$ & $\begin{array}{l}3833 \\
(9.54)\end{array}$ \\
\hline 2 & Digging and filling of pits ${ }^{1}$ & $\begin{array}{l}995 \\
(2.61) \\
\end{array}$ & $\begin{array}{l}1250 \\
(3.03)\end{array}$ & $\begin{array}{l}1100 \\
(2.67) \\
\end{array}$ & $\begin{array}{l}1115 \\
(2.77) \\
\end{array}$ \\
\hline 3 & Manures and fertilizers & $\begin{array}{l}7775 \\
(20.43)\end{array}$ & $\begin{array}{l}9500 \\
(23.03)\end{array}$ & $\begin{array}{l}10000 \\
(24.33)\end{array}$ & $\begin{array}{l}9091 \\
(22.63)\end{array}$ \\
\hline 4 & Cost of plant ${ }^{2}$ & $\begin{array}{l}1650 \\
(4.33)\end{array}$ & $\begin{array}{l}1800 \\
(4.36)\end{array}$ & $\begin{array}{l}1700 \\
(4.13)\end{array}$ & $\begin{array}{l}1761 \\
(4.38) \\
\end{array}$ \\
\hline 5 & Transportation of plant & $\begin{array}{l}850 \\
(2.23) \\
\end{array}$ & $\begin{array}{l}750 \\
(1.81) \\
\end{array}$ & $\begin{array}{l}700 \\
(1.70) \\
\end{array}$ & $\begin{array}{l}766 \\
(1.90) \\
\end{array}$ \\
\hline 6 & Plantation cost & $\begin{array}{l}1320 \\
(3.47)\end{array}$ & $\begin{array}{l}1350 \\
(3.27)\end{array}$ & $\begin{array}{l}1150 \\
(2.79)\end{array}$ & $\begin{array}{l}1273 \\
(3.16)\end{array}$ \\
\hline 7 & Cost of irrigation $^{3}$ & $\begin{array}{l}11500 \\
(30.23) \\
\end{array}$ & $\begin{array}{l}11000 \\
(26.66) \\
\end{array}$ & $\begin{array}{l}11800 \\
(28.71) \\
\end{array}$ & $\begin{array}{l}11433 \\
(28.46) \\
\end{array}$ \\
\hline 8 & Intercultural operations & $\begin{array}{l}2400 \\
(6.30)\end{array}$ & $\begin{array}{l}2600 \\
(6.30)\end{array}$ & $\begin{array}{l}2700 \\
(6.56)\end{array}$ & $\begin{array}{l}2566 \\
(6.38) \\
\end{array}$ \\
\hline 9 & Cutting and Pruning & $\begin{array}{l}2800 \\
(7.36)\end{array}$ & $\begin{array}{l}3000 \\
(7.27)\end{array}$ & $\begin{array}{l}2400 \\
(5.83)\end{array}$ & $\begin{array}{l}2733 \\
(6.80)\end{array}$ \\
\hline 10 & Permanent fencing & $\begin{array}{l}2250 \\
(5.91)\end{array}$ & $\begin{array}{l}3000 \\
(7.27)\end{array}$ & $\begin{array}{l}2600 \\
(6.32)\end{array}$ & $\begin{array}{l}2616 \\
(6.51)\end{array}$ \\
\hline \multirow[t]{2}{*}{11} & Miscellaneous & $\begin{array}{l}2850 \\
(7.49)\end{array}$ & $\begin{array}{l}3000 \\
(7.27)\end{array}$ & $\begin{array}{l}3100 \\
(7.54)\end{array}$ & $\begin{array}{l}2983 \\
(7.42)\end{array}$ \\
\hline & Total & $\begin{array}{l}38040 \\
(100.00)\end{array}$ & $\begin{array}{l}41250 \\
(100.00)\end{array}$ & $\begin{array}{l}41100 \\
(100.00)\end{array}$ & $\begin{array}{l}40170 \\
(100.00)\end{array}$ \\
\hline
\end{tabular}

Note: - Figures in parentheses are the percentage to the total establishment cost.

(1) Rs 72 per pit given by Government under NHM

(2) Rs. 20 percent subsidy given by the Government under NHM

(3) 75 percent subsidy given government under NHM

\section{Overall average cost and return from guava orchard}

The Table 3 shows that there was no production of guava up to the age of two years since the bearing of fruits usually starts after attaining two years of age. The per hectare production of fruits starts increasing gradually from nearly 24 quintals in three year to about 210 quintals in seventh year orchard age. However, after attaining the age of seven year it remain almost static with advance in age of the plants. Hence, the gross returns per hectare from guava orchard increased up to seventh year of the plant age. The gross returns per hectare worked out to be Rs. 178500 in the seventh year that was full bearing stage. Even after taking the returns from intercropping in the orchard the orchardist has to bear a loss of Rs. 19518, Rs. 25690 and Rs. 21546 per hectare in first, second and third year, respectively. During the fourth year, the net returns become positive and worked out to be Rs. 2269 per hectare. The net returns increased upto seventh year i.e. Rs. 71947 per hectare and after that it became more or less Table upto the age of 25 to 30 years. The overall average net returns from the intercropping range from Rs. 39371 in the first year to Rs. 25438 per hectare during the fifth year of the orchard. Thus, the negative returns during early years of guava cultivation reduced substantially from Rs. 58889, Rs. 60968, Rs. 54276, Rs. 29660 per hectare to be Rs. 19518, Rs. 25690 and Rs. 21546 per hectare for one, two, third and fourth years age orchards, respectively owing to return from intercropping. These results got the support from the findings reported by Dahiya (2002), Mishra et al. (2000) and Naphade and Tingre (2008).

Table 2: Operational cost of Guava orchard in Hisar, Fatehabad and Sirsa district in Haryana $\left(/ \mathbf{h a}^{-1}\right)$

\begin{tabular}{|c|c|c|c|c|c|c|c|c|c|c|}
\hline \multirow{2}{*}{$\begin{array}{l}\text { Sr. } \\
\text { No } \\
.\end{array}$} & \multirow[t]{2}{*}{ Particulars } & \multicolumn{7}{|l|}{ Years } & \multirow{2}{*}{$\begin{array}{l}\text { Total } \\
\text { cost }\end{array}$} & \multirow{2}{*}{$\begin{array}{l}\text { Average } \\
\text { cost } \\
\text { per } \\
\text { Annum }\end{array}$} \\
\hline & & 1 & 2 & 3 & 4 & 5 & 6 & 7 & & \\
\hline 1 & $\begin{array}{l}\text { Intercultural } \\
\text { operation } \\
\text { and Hoeing }\end{array}$ & $\begin{array}{l}1110 \\
(18.04)\end{array}$ & $\begin{array}{l}1514 \\
(18.90)\end{array}$ & $\begin{array}{l}1732 \\
(8.55)\end{array}$ & $\begin{array}{l}2330 \\
(9.38)\end{array}$ & $\begin{array}{l}2610 \\
(9.01)\end{array}$ & $\begin{array}{l}2900 \\
(7.78)\end{array}$ & $\begin{array}{l}3540 \\
(7.26)\end{array}$ & $\begin{array}{l}15736 \\
(9.03)\end{array}$ & $\begin{array}{l}2248 \\
(9.03)\end{array}$ \\
\hline 2 & $\begin{array}{ll}\text { Manures } & \text { and } \\
\text { Fertilizers }^{1} & \end{array}$ & - & - & $\begin{array}{l}5810 \\
(28.69)\end{array}$ & $\begin{array}{l}6800 \\
(27.38)\end{array}$ & $\begin{array}{l}7460 \\
(25.76)\end{array}$ & $\begin{array}{l}8200 \\
(21.99)\end{array}$ & $\begin{array}{l}9750 \\
(20.01)\end{array}$ & $\begin{array}{l}38020 \\
(21.82 \\
)\end{array}$ & $\begin{array}{l}5431 \\
(21.82)\end{array}$ \\
\hline 3 & $\begin{array}{l}\text { Drip maintainances } \\
\text { and irrigation }\end{array}$ & $\begin{array}{l}868 \\
(14.10) \\
\end{array}$ & $\begin{array}{l}980 \\
(12.23) \\
\end{array}$ & $\begin{array}{l}1030 \\
(5.08)\end{array}$ & $\begin{array}{l}1200 \\
(4.83)\end{array}$ & $\begin{array}{l}1300 \\
(4.48)\end{array}$ & $\begin{array}{l}2500 \\
(6.70)\end{array}$ & $\begin{array}{l}4000 \\
(8.21)\end{array}$ & $\begin{array}{l}11878 \\
(6.81)\end{array}$ & $\begin{array}{l}1697 \\
(6.81)\end{array}$ \\
\hline 4 & Prunning and cutting & $\begin{array}{l}880 \\
(14.30)\end{array}$ & $\begin{array}{l}1156 \\
(14.43)\end{array}$ & $\begin{array}{l}1350 \\
(6.66)\end{array}$ & $\begin{array}{l}1480 \\
(5.96)\end{array}$ & $\begin{array}{l}2557 \\
(8.89)\end{array}$ & $\begin{array}{l}3655 \\
(9.80)\end{array}$ & $\begin{array}{l}5520 \\
(11.33)\end{array}$ & $\begin{array}{l}16598 \\
(9.52)\end{array}$ & $\begin{array}{l}2371 \\
(9.52)\end{array}$ \\
\hline 5 & $\begin{array}{l}\text { Insecticides and } \\
\text { Fungicides }^{2}\end{array}$ & - & - & $\begin{array}{l}4336 \\
(21.41)\end{array}$ & $\begin{array}{l}5700 \\
(22.95)\end{array}$ & $\begin{array}{l}6500 \\
(22.44)\end{array}$ & $\begin{array}{l}7700 \\
(20.65)\end{array}$ & $\begin{array}{l}8999 \\
(18.47)\end{array}$ & $\begin{array}{l}33235 \\
(19.08\end{array}$ & $\begin{array}{l}4748 \\
(19.08)\end{array}$ \\
\hline
\end{tabular}


Economics Analysis Of Guava Production In Haryana

\begin{tabular}{|c|c|c|c|c|c|c|c|c|c|c|}
\hline & & & & & & & & & ) & \\
\hline 6 & Watch and Ward & $\begin{array}{l}1300 \\
(21.13)\end{array}$ & $\begin{array}{l}1470 \\
(18.35)\end{array}$ & $\begin{array}{l}1689 \\
(8.34)\end{array}$ & $\begin{array}{l}1866 \\
(7.51)\end{array}$ & $\begin{array}{l}2133 \\
(7.36)\end{array}$ & $\begin{array}{l}2456 \\
(6.58)\end{array}$ & $\begin{array}{l}3100 \\
(6.36)\end{array}$ & $\begin{array}{l}14014 \\
(8.04)\end{array}$ & $\begin{array}{l}2002 \\
(8.04)\end{array}$ \\
\hline 7 & Picking cost & - & - & $\begin{array}{l}1300 \\
(6.42)\end{array}$ & $\begin{array}{l}2300 \\
(9.26)\end{array}$ & $\begin{array}{l}2899 \\
(10.01)\end{array}$ & $\begin{array}{l}5500 \\
(14.75)\end{array}$ & $\begin{array}{l}7800 \\
(16.01)\end{array}$ & $\begin{array}{l}19799 \\
(11.36 \\
\end{array}$ & $\begin{array}{l}2828 \\
(11.36)\end{array}$ \\
\hline 8 & Miscellanous & $\begin{array}{l}1994 \\
(32.41)\end{array}$ & $\begin{array}{l}2888 \\
(36.06)\end{array}$ & $\begin{array}{l}3000 \\
(14.81)\end{array}$ & $\begin{array}{l}3155 \\
(12.70)\end{array}$ & $\begin{array}{l}3500 \\
(12.08)\end{array}$ & $\begin{array}{l}4363 \\
(11.70)\end{array}$ & $\begin{array}{l}6000 \\
(12.31)\end{array}$ & $\begin{array}{l}24900 \\
(14.29 \\
)^{2}\end{array}$ & $\begin{array}{l}3557 \\
(14.29)\end{array}$ \\
\hline & Total cost & $\begin{array}{l}6152 \\
(100.00 \\
)\end{array}$ & $\begin{array}{l}8008 \\
(100.00)\end{array}$ & $\begin{array}{l}20247 \\
(100.00)\end{array}$ & $\begin{array}{l}24831 \\
(100.00)\end{array}$ & $\begin{array}{l}28959 \\
(100.00)\end{array}$ & $\begin{array}{l}37274 \\
(100.00)\end{array}$ & $\begin{array}{l}48709 \\
(100.00)\end{array}$ & $\begin{array}{l}17418 \\
0 \\
(100.0 \\
0)\end{array}$ & $\begin{array}{l}24883 \\
(100.00)\end{array}$ \\
\hline
\end{tabular}

Note: - Figures in parentheses are the percentage to the average cost per annum.

(1) Rs. 6000 per hectare subsidy for two year given by government under NHM

(2) Rs. 6000 per hectare subsidy for two year given by government under NHM

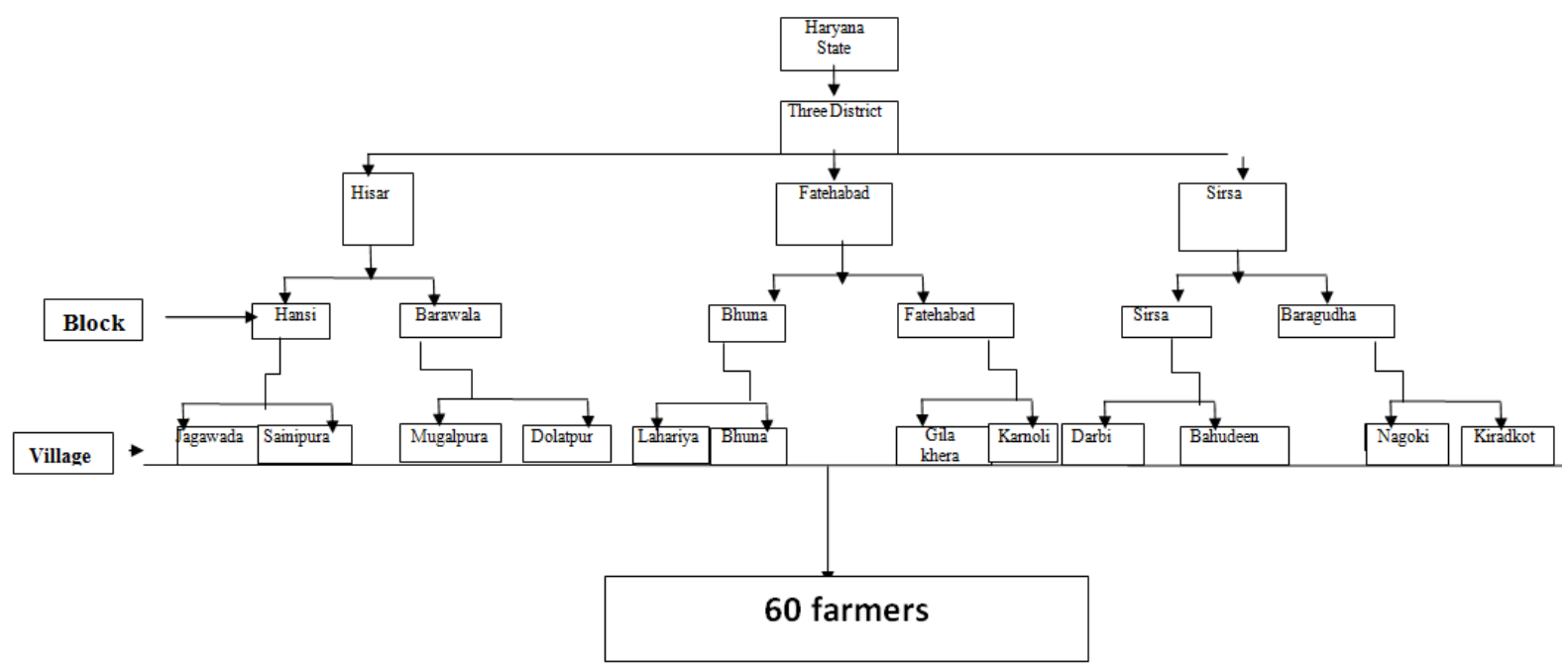

Fig. 1: Sampling procedure adopted in the study area

Table 3: Overall average Cost and return from Guava orchard in Hisar, Fatehabad and Sirsa district

\begin{tabular}{|c|l|c|c|c|c|c|c|c|}
\hline Sr. No. & Particulars & \multicolumn{3}{|c|}{ Years } \\
\cline { 3 - 9 } & & $\mathbf{1}$ & $\mathbf{2}$ & $\mathbf{3}$ & $\mathbf{4}$ & $\mathbf{5}$ & $\mathbf{6}$ & $\mathbf{7}$ \\
\hline 1 & Land rent & 45000 & 45000 & 45000 & 45000 & 45000 & 45000 & 45000 \\
\hline 2 & Amortized fixed cost & 5121 & 5121 & 5121 & 5121 & 5121 & 5121 & 5121 \\
\hline 3 & operational cost & 6152 & 8008 & 20247 & 24831 & 28959 & 37274 & 48709 \\
\hline 4 & Expected depreciation on fixed cost investment @4 \% & 1606 & 1606 & 1606 & 1606 & 1606 & 1606 & 1606 \\
\hline 5 & Interest on operational cost @12\%per annum & 738 & 961 & 2430 & 2980 & 3475 & 4473 & 5845 \\
\hline 6 & Total cost & 58889 & 60968 & 74676 & 79810 & 84433 & 93746 & 106553 \\
\hline 7 & Production (qtls) & - & - & 24 & 59 & 107 & 158 & 210 \\
\hline 8 & Gross return\# & 0 & 0 & 20400 & 50150 & 90950 & 134300 & 178500 \\
\hline 9 & Net return from guava & -58889 & -60968 & -54276 & -29660 & 6517 & 40554 & 71947 \\
\hline 10 & Return from intercropping & 39371 & 35278 & 32730 & 31929 & 25438 & 0 & 0 \\
\hline & Total net returns & $\mathbf{- 1 9 5 1 8}$ & $\mathbf{- 2 5 6 9 0}$ & $\mathbf{- 2 1 5 4 6}$ & $\mathbf{2 2 6 9}$ & $\mathbf{1 8 9 2 1}$ & $\mathbf{4 0 5 5 4}$ & $\mathbf{7 1 9 4 7}$ \\
\hline
\end{tabular}

\#Gross return has been worked out by taking average price (Rs. 850 per quintal) received by the farmers during peak marketing season of the current period in $\mathrm{t}$ 


\section{References}

[1]. Acharya, S.S. and Agarwal, N.L. (2011). Market Integration, Efficiency, Costs, Margins and Price Spread. Agril. Mktg. in Ind. 440443.

[2]. Anonymous 2010. Haryana Horticulture Database. Directorate of Horticulture, Haryana.

[3]. Dahiya, Pawan (2002). Cost-Benefit analysis of Ber cultivation in Rohtak District of Haryana. Ind. J. Agril. Mktg. 16(2): 48-52.

[4]. Mishra, J. P., Ramachandra and Rawat, S. K. (2000). Production and marketing of Banana in Gorakhpur district of Uttar Pradesh, Agril. Mktg, pp. 36-40.

[5]. Naphade S.A. and Tingre A.S. (2008). Economics of production and marketing of guava in buldhana district of Maharashtra. Ind. J. Agril. Mktg. 22(2): 32-41.

[6]. Reddy, S.S., Ram, R. P., Sastry, T.V.N. and Devi, B.I., (2010). Agricultural Projects. Agril. Econ. 474-480.

[7]. Umesh, K.B., Vishnuvardhana and Thirumalaraju, G.T. (2005). Business opportunities in cashew industry. Agro-India The Integrated Agribusiness Magazine, 8(1): 14-17. 